TRADITIONS OF ELOQUENCE 
This page intentionally left blank 


\section{TRADITIONS OF ELOQUENCE}

The Jesuits and Modern Rhetorical Studies

CINTHIA GANNETT AND

JOHN C. BRERETON, EDITORS 
Copyright (C) 2016 Fordham University Press

All rights reserved. No part of this publication may be reproduced, stored in a retrieval system, or transmitted in any form or by any meanselectronic, mechanical, photocopy, recording, or any other-except for brief quotations in printed reviews, without the prior permission of the publisher.

Fordham University Press has no responsibility for the persistence or accuracy of URLs for external or third-party Internet websites referred to in this publication and does not guarantee that any content on such websites is, or will remain, accurate or appropriate.

Fordham University Press also publishes its books in a variety of electronic formats. Some content that appears in print may not be available in electronic books.

Visit us online at www.fordhampress.com.

Library of Congress Cataloging-in-Publication Data

Traditions of eloquence : the Jesuits and modern rhetorical studies / edited by Cinthia Gannett and John Brereton. - First edition.

pages $\mathrm{cm}$

Includes bibliographical references and index. ISBN 978-o-8232-6452-o (cloth : alk. paper) ISBN 978-0-8232-6453-7 (pbk. : alk. paper)

1. Rhetoric-Study and teaching (Higher)

2. Jesuits-Education (Higher) I. Gannett, Cinthia, 1959-, editor. II. Brereton, John, 1943- editor.

P53.27.T728 2015

808.0o88'27153-dc23

2015018253

Printed in the United States of America

$\begin{array}{llllllll}18 & 17 & 16 & 5 & 4 & 3 & 2 & 1\end{array}$

First edition 